\section{CHALLENGES OF HANDICRAFT PRODUCTS MARKETING AND PROMOTION AMONGST IBAN ENTREPRENEURS IN SARAWAK}

\author{
Noria Anak Tugang \\ Universiti Malaysia Sarawak \\ Ngalih Anak Tingi \\ Universiti Malaysia Sarawak
}

Corresponding Author

tnoria@unimas.my

ngalihtingi@gmail.com.my
The main objective of this study was to examine challenges faced by handicraft marketing in implementing product promotion strategies amongst Iban entrepreneurs in Sarawak. This study specifically focused on strategy, the effectiveness of the strategy, and the challenges in implementing the promotion strategy. Fieldwork was carried out at several locations in Kapit and Song district. The data were collected through open-ended questionnaires by email and followed by face-to-face interviews with the respondents. The result showed that personal selling is the effective strategy and the other promotion strategies through public relations. Social media like Facebook, WhatsApp, Instagram, personal selling, and trade fairs are not commonly applicable. Government negligence, exploitation, lack of training, lack of financial support, lack of promotion assistance from stakeholders, expensive working tools, and lack of ownership to the working places were the most critical challenges these marketing strategies face, especially in the rural area. The study recommends that the government come up with support or policies that would create an environment for all stakeholders, including financial institutions, training institutions, and NGOs, to lend a helping hand in promoting skills development in the area.

Keywords: entrepreneurs, handicraft, Iban, rural development, marketing strategies 


\section{INTRODUCTION}

Small industries, particularly handicraft productions, are a significant form of employment, and in every nation, it constitutes a substantial part of their export economy. Observers in the handicraft sector predict that the escalating number of small businesses turning to handicraft production is unlikely to decline significantly in the future. Artisans have been identified as the second-largest sector of rural employment after agriculture in many regions of the world (Rutashobya and Jaenssson, 2004).

The Sarawak Handicraft Industry, especially amongst Iban people, is based on traditional products and traditional processes. It is also based on the comparative advantage of a rich and readily available supply of quality raw materials. In the Iban community, the most popular products are non-timber such as baskets, mats, and textiles (weavings). There is a strong link between tourism and handicrafts of East Malaysians. There is also an interest in contemporary design products and more functional purposes (e.g.: kain burie).

Almost all inputs present a problem: skilled human resources, finance, raw materials, machinery/spare parts, and sometimes information. The long distances involved in distribution, prohibitive transport costs (due to extremely high prices for fuel and spare parts, and the deplorable state main roads), and complex communications have led to ever-higher black-market prices. As the cost of living has sky-rocketed, the purchasing power of the people has declined, thus creating market problems for all industry including Small Scale Industry (SSI).

The small-scale of activities itself results in poor competitiveness because, for instance, bulk buying of required raw materials at reasonable prices is not possible. The labour skills are often focused on only one person, the owner, instead of the workers specializing in specific production steps. Furthermore, production methods and techniques are often obsolete and result in higher costs and lower quality products. Finally, the entrepreneur appears indifferent to market dictates, being more strongly influenced by culture and environment. SSIs are noted for making products according to the entrepreneurs' wishes, skills, and standards rather than market wishes (Hay, 2008).

The survival and success of handicraft marketing largely depend on the promotion strategies that enable the sellers to make the buyers aware, attract and retain buyers for the crafts. Thus, successful results are achieved with more effective promotion strategies, and attractive financial earning is realized. Handicraft marketing is one of the businesses lagging by the lack of proper promotion strategies to attract buyers. 
Promotion for handicrafts is passive as sellers, primarily in the Iban community far away from town, tend to rely on word of mouth and wait for buyers to come (Grobler,2005).While recognizing these problems, the areas of intervention by donor agencies can rest on the following three main pillars; policy framework formulation for artisan craft promotion and preservation, institutional capacity building for implementing the support programmes and activities, and strengthening the managerial and production capability of craft producing companies. Also, improve the technical skills of craftspeople (The United Nations Educational, Scientific and Cultural Organization [UNESCO], 2000). The contribution of the handicraft industry has little impact as a result of no full recognition. Perhaps the key challenges and effective measures have not yet been determined. Thus, the new study expects to develop the most crucial challenges facing the handicraft marketing industry.

This study will facilitate society members in dealing with challenges faced by handicraft promotion, especially in Iban handicraft products. Specifically, handicraft businesses will get knowledge on strategies established for promoting handicraft businesses, hindering handicraft marketing in promoting their products, and then applying good alternatives in promoting handicraft businesses. For instance, academicians and policymakers will use the study as the source of references while dealing with handicraft businesses' challenges in promoting their products in the Kapit and Song district, including conducting more research and establishing policies and programs. Meanwhile, the study will facilitate a review of measures taken to promote handicraft marketing products in Sarawak.

\section{METHOD}

In the census 2000, Kapit Division recorded a total population of 98,841 people, which constituted only $4.9 \%$ of the total population in Sarawak $(2,009,893)$. Population by district is Kapit: 56,709, Song: 19,236 and Belaga: 22,896 meanwhile population density is 2.5 (person per sq $\mathrm{km}$ ). About $88.4 \%$ of the population settles in rural areas, and $57.4 \%$ resides in Kapit District. The Iban are the largest ethnic group in Kapit, at $67.4 \%$. The rest are Orang Ulu (18.7\%), Chinese (6.7\%), Malay (3.4\%), and Melanau (1.2\%).

Based on these populations, Kapit and Song districts were chosen as most Iban handicraft entrepreneurs are found here, and some are far from town. A case study is an in-depth study that allows a researcher to examine a particular issue or problem involving an individual, program, or event in detail concentrated within a certain period (Ahmad et al., 2014). The case study design collects the information among craftspeople in the Kapit and Song districts in this study. Using the case study design 
allows the researcher to study the background and organization through an in-depth interview by focusing on an individual and others.

The research technique will use the in-depth interview to conduct this study. According to Ahmad et al., (2014), in qualitative methodology; the interview is one of the popular research techniques. It allows the research to have a direct conversation with the informant to provide the answer. The in-depth interviews can be face-to-face, telephone interviews, and open-ended questionnaires can be used to collect data. In this study, the researcher used open-ended questionnaires through email followed by face-to-face interviews with all informants. Demographic information of informants will be collected as well. The open-ended questionnaires are divided into two parts. Part one is warming up questions asking for informant condition today. Part two is situating questions which as briefly about their general knowledge on handicrafts. Part three was the central question for the informants to write down their perception of problems or challenges and explained more detail during face-to-face interviews based on the objective question. At the same time, the last part is the demographic information of informants, which is also the informant's background.

\section{DISCUSSION AND FINDINGS}

Interview on handicraft production is part of the overall socio-economic and environmental study in rural areas of Kapit District. Twelve respondents were chosen based on quota sampling and consultation with Kapit and Song Resident Office and Serakup Induk Dayak Sarawak (SIDS), Kapit Branch. All informant's real names, gender, and age are kept confidential to preserve their identity.

Table 1: Number of Respondents

\begin{tabular}{|l|l|}
\hline The number of Respondents & Actual No. Respondents \\
\hline Kapit District & $8(66.7 \%)$ \\
\hline Song District & $4(33.3 \%)$ \\
\hline Total & 12 \\
\hline
\end{tabular}

Source. Fieldwork Data

Table 1 presents the distribution of respondents by district location of their businesses. A total of 12 valuable informants chooses for conducting an in-depth face-to-face interview with are expert handicrafts products and well established. Two district centers were involved Kapit and Song Districts with 12 respondents. 
Table 2 present the distribution of respondents by district location of their businesses. A total of 12 helpful in conducting semi-structured in-depth interviews with a marketing expert of the handicrafts industry. Two district centers were involved Kapit and Song Districts with 12 respondents.

Table 2: Respondents and their Handicraft Products

\begin{tabular}{|c|c|c|c|}
\hline District & $\begin{array}{l}\text { No. } \\
\text { Respondent }\end{array}$ & $\begin{array}{l}\text { Type of } \\
\text { Handicraft } \\
\text { Products }\end{array}$ & Product Samples \\
\hline Kapit & Informant 1 & $\begin{array}{l}\text { Rattan basket } \\
\text { and bemban } \\
\text { mat }\end{array}$ & \\
\hline Kapit & Informant 2 & $\begin{array}{l}\text { Rattan, plastic } \\
\text { basket }\end{array}$ & \\
\hline Kapit & Informant 3 & $\begin{array}{l}\text { weave textile } \\
\text { (tenunan) }\end{array}$ & \\
\hline
\end{tabular}




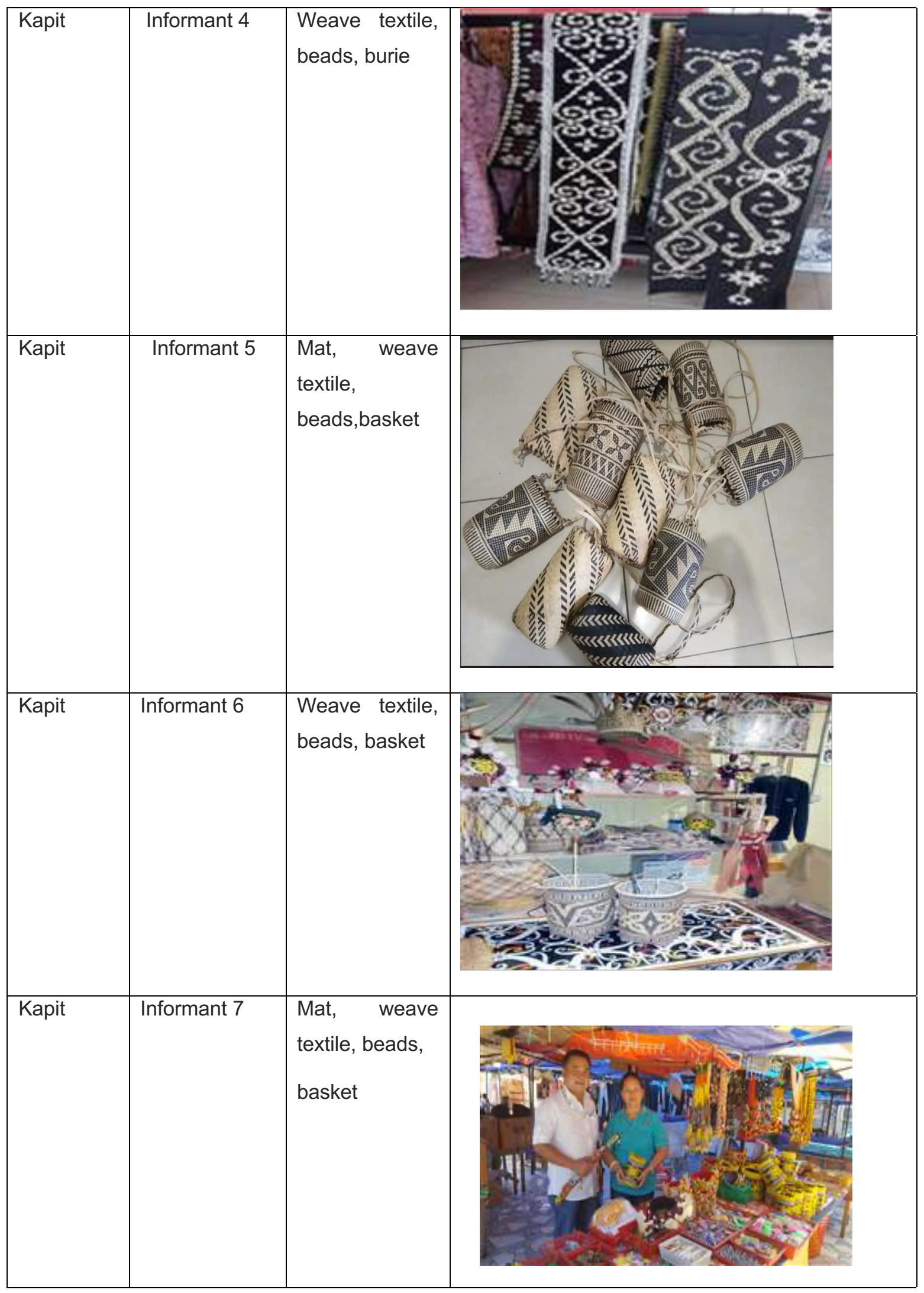




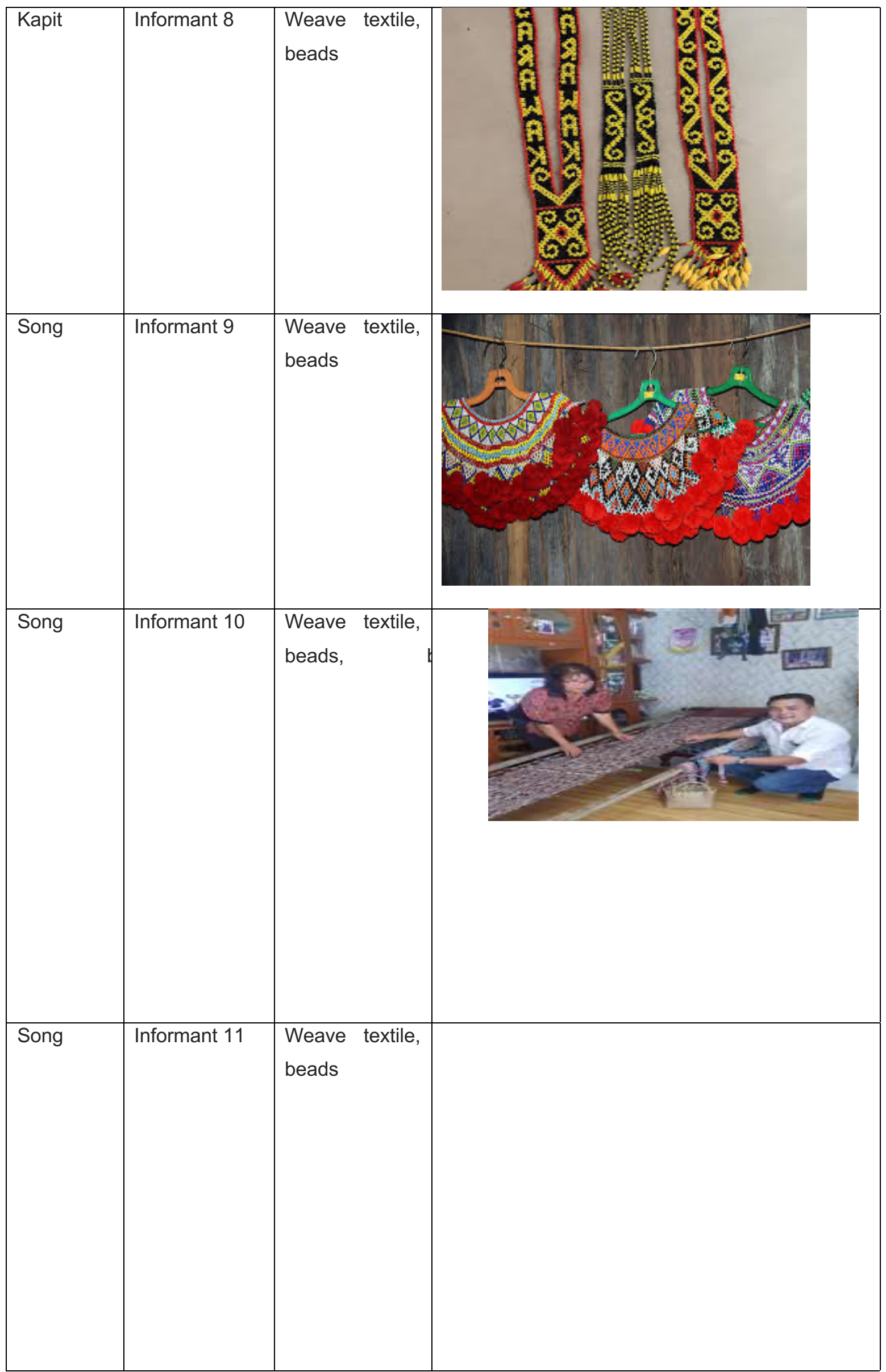




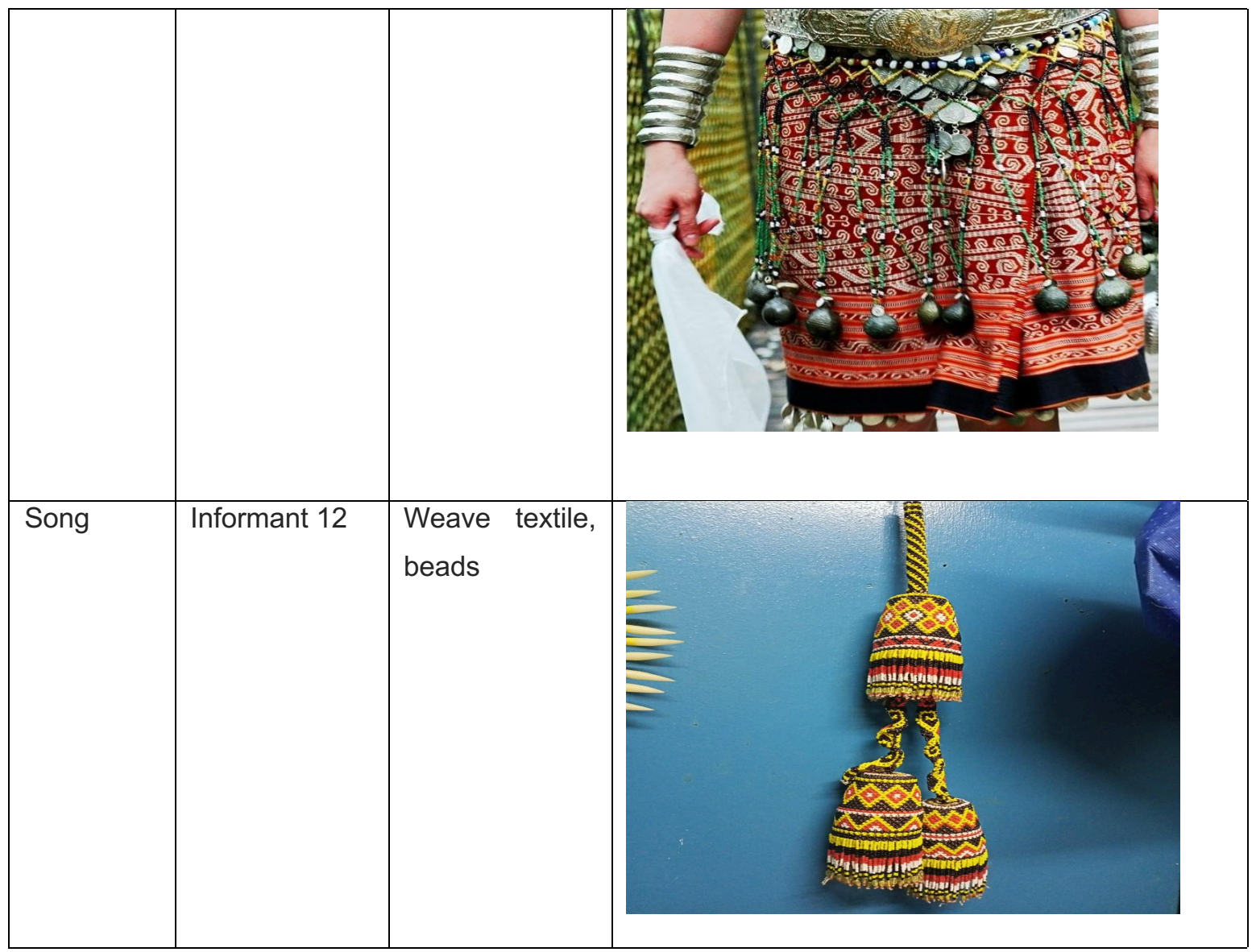

The main reason for continuing the tradition includes interest, way of life and selfconsumption, seeking additional income, killing time, and upholding handicraft products as part of their identity and culture heritage. Many of the informants I studied were making and selling handicrafts of textile, beads, burie and basket and mats made of bemban (Donax canniformis) and rattan (Calamus).

Table 3: Reason for pursuing handicraft production, challenges, and marketing strategies

\begin{tabular}{|l|l|l|l|l|}
\hline District & Informant & $\begin{array}{l}\text { Reason for pursuing } \\
\text { handicraft production }\end{array}$ & $\begin{array}{l}\text { Challenges } \\
\text { sustaining handicraft } \\
\text { production }\end{array}$ & Marketing Strategies \\
\hline Kapit & 1 & $\begin{array}{l}\text { Additional income, } \\
\text { interest, identity, and } \\
\text { cultural heritage }\end{array}$ & $\begin{array}{l}\text { Marketing and access } \\
\text { to hard-to-find and } \\
\text { expensive natural raw } \\
\text { material }\end{array}$ & $\begin{array}{l}\text { Advertising and } \\
\text { promotion by social } \\
\text { media. } \\
\text { Facebook, Instagram, } \\
\text { and WhatsApp's }\end{array}$ \\
\hline Kapit & 2 & $\begin{array}{l}\text { Additional income, } \\
\text { interest, identity, and }\end{array}$ & $\begin{array}{l}\text { Marketing and access } \\
\text { to hard-to-find and } \\
\text { expensive natural raw }\end{array}$ & Advertising and booth \\
\hline
\end{tabular}




\begin{tabular}{|c|c|c|c|c|}
\hline & & cultural heritage & material & \\
\hline Kapit & 3 & Additional income & $\begin{array}{l}\text { Marketing and access } \\
\text { to hard-to-find and } \\
\text { expensive natural raw } \\
\text { material }\end{array}$ & Advertising and booth \\
\hline Kapit & 4 & Additional income & $\begin{array}{l}\text { Marketing and } \\
\text { expensive raw material } \\
\text { odder from China and } \\
\text { Indonesia }\end{array}$ & $\begin{array}{l}\text { Older, } \\
\text { promoting by family } \\
\text { and friend }\end{array}$ \\
\hline Kapit & 5 & $\begin{array}{l}\text { Additional income and } \\
\text { interest }\end{array}$ & $\begin{array}{l}\text { Marketing and access } \\
\text { to hard-to-find and } \\
\text { expensive natural raw } \\
\text { material }\end{array}$ & $\begin{array}{l}\text { Older, } \\
\text { promoting by family } \\
\text { and friend }\end{array}$ \\
\hline Kapit & 6 & $\begin{array}{l}\text { Additional income, } \\
\text { interest, identity, and } \\
\text { cultural heritage }\end{array}$ & $\begin{array}{l}\text { Marketing and access } \\
\text { to hard-to-find and } \\
\text { expensive natural raw } \\
\text { material }\end{array}$ & $\begin{array}{l}\text { Advertising and } \\
\text { promotion by social } \\
\text { media. Example: } \\
\text { Facebook, Instagram, } \\
\text { and WhatsApp }\end{array}$ \\
\hline Kapit & 7 & $\begin{array}{l}\text { Way of life and self- } \\
\text { consumption. } \\
\text { Additional income }\end{array}$ & $\begin{array}{l}\text { Marketing and access } \\
\text { to hard-to-find and } \\
\text { expensive natural raw } \\
\text { material }\end{array}$ & $\begin{array}{l}\text { Advertising and } \\
\text { promotion by social } \\
\text { media. Example: } \\
\text { Facebook, Instagram, } \\
\text { and WhatsApp's }\end{array}$ \\
\hline Kapit & 8 & $\begin{array}{l}\text { Additional income, } \\
\text { interest, identity, and } \\
\text { cultural heritage }\end{array}$ & $\begin{array}{l}\text { Marketing and access } \\
\text { to hard-to-find and } \\
\text { expensive natural raw } \\
\text { material }\end{array}$ & $\begin{array}{l}\text { Advertising and } \\
\text { promotion by social } \\
\text { media. Example: } \\
\text { Facebook, Instagram, } \\
\text { and WhatsApp's }\end{array}$ \\
\hline Song & 9 & $\begin{array}{l}\text { Additional income, } \\
\text { interest, identity, and } \\
\text { cultural heritage }\end{array}$ & $\begin{array}{l}\text { Marketing and access } \\
\text { to hard-to-find and } \\
\text { expensive natural raw } \\
\text { material }\end{array}$ & $\begin{array}{l}\text { Advertising and } \\
\text { promotion by social } \\
\text { media. Example: } \\
\text { Facebook, Instagram, } \\
\text { and WhatsApp's }\end{array}$ \\
\hline Song & 10 & $\begin{array}{l}\text { Additional income, } \\
\text { interest, identity, and } \\
\text { cultural heritage }\end{array}$ & $\begin{array}{l}\text { Marketing and access } \\
\text { to hard-to-find and } \\
\text { expensive natural raw } \\
\text { material }\end{array}$ & $\begin{array}{l}\text { Advertising } \\
\text { promotion by social } \\
\text { media. } \\
\text { Facebook, Instagram, }\end{array}$ \\
\hline
\end{tabular}




\begin{tabular}{|l|l|l|l|l|}
\hline & & & & \multicolumn{2}{|l|}{ and WhatsApp's } \\
\hline Song & 11 & $\begin{array}{l}\text { Additional income, } \\
\text { interest, identity, and } \\
\text { cultural heritage }\end{array}$ & $\begin{array}{l}\text { Marketing and access } \\
\text { to hard-to-find and } \\
\text { expensive natural raw } \\
\text { material }\end{array}$ & $\begin{array}{l}\text { Advertising and } \\
\text { promotion by social } \\
\text { media. Example: } \\
\text { Facebook, Instagram, } \\
\text { and WhatsApp's }\end{array}$ \\
\hline Song & 12 & $\begin{array}{l}\text { Additional income, } \\
\text { interest, identity, and } \\
\text { cultural heritage }\end{array}$ & $\begin{array}{l}\text { Marketing and access } \\
\text { to hard-to-find and } \\
\text { expensive natural raw } \\
\text { material }\end{array}$ & $\begin{array}{l}\text { Advertising and } \\
\text { promotion by social } \\
\text { media. Example: } \\
\text { Facebook, Instagram } \\
\text { and WhatsApp's }\end{array}$ \\
\hline
\end{tabular}

Source. Fieldwork data

Many informants stated that they work on these handicrafts because they are descended from their ancestors, interested in filling the free space, and increasing family income. Today, the demand for original handicrafts, especially in Iban Crafts, is very high, and the income benefits them. However, getting raw materials such as rattan and bemban in the forest is very difficult. Also, yarn which is used in weaving is very expensive and the material to produce burie cloth must be imported or bought from neighboring countries such as Indonesia and China.

The majority of the Iban handicraft entrepreneurs do not have a specific marketing strategy. Some wait for tourists and visitors to buy their product to exchange for cash. Besides, some of them ask their family member to advertise and promote their crafts on social media. Being the active members in handicraft production, a stable demand certainly encourages the producers to invest more in buying the raw materials and incentives for more entrepreneurs to participate in handicraft production and businesses actively. Nevertheless, the main challenges are related to the price and the difficulty of obtaining raw natural materials such rattan, yarn, and beads for the handicrafts, improper platform to market the products-lack of interest by the younger generation to continue the product's tradition. The lack of marketing channels for producers was also a concern as many producers place heavy reliance on the local tourist trade in their area.

\section{CONCLUSION}

The study results show that Iban handicraft products in rural areas, especially Kapit and Song District, are based on personal selling; thus, the marketing mix lacks. There is sufficient awareness of the other be concluded that to the extent that unique selling strategy is applied, it is effective. However, the overdependence on personal selling 
has resulted in low sales with vast handicraft stocks, un-employed. Eventually, it may lead to the demise of the handicraft sector. Moreover, the industry faces many challenges, mainly from the lack of government and other stakeholder involvement, lack of training, lack of financial assistance, lack of service in promotion, etc.

The Sarawak Handicraft Council and Malaysian Handicraft Development Corporation Sarawak Branch, Tours Operator, and NGOs should give support by advertising and promoting handicrafts. The handicraft sector needs collective effort of national and international stakeholder to break the vicious cycle of these challenges and bail them out of world economic doldrums by offering education in particular ICT, a leadership seminar to enable them to re-organize, offer training for the artists, especially among the young generations to enable them to acquire formal knowledge to evolve with culture to retain and attract more handicraft customers.

\section{REFERENCES}

1. Ahmad, R., Usop, H., Ismail, A., Bujang, S., \& Abu Mansor, N.N. (2014). Conducting research in social and management studies. Malaysia:RS Publishing HouseJ. Clerk Maxwell, $A$ Treatise on Electricity and Magnetism, $3^{\text {rd }}$ ed., vol. 2. Oxford: Clarendon, 1892, pp.68-73.

2. Awuah, E. (2011). The Craft Industry and its Challenges, Business Guide Newspaper. Available at http://www.businessguideghana.com/p35

3. Belch, G. and Belch, M. (2007). Advertising and Promotion: An Integrated Marketing Communication Perspective. 5th Edition. Boston: Irwin/McGraw-Hill.

4. Chamhuri, S., Ahmad, M. Z., \& Abdul, H. J. (1990). Peranan Industri Desa dalam Pembangunan Industri. Jurnal Ekonomi Malaysia, 21 \& 22: 265 - 304.

5. Charles, W. L. H., \& Gareth, R. J. (2001). Strategic Management an Integrated Approach Theory Annual Update. South-Western: Cengage Learning.

6. Churchill, G. (2006). Basic Marketing Research. 3rd Edition. Orlando Florida: The Dryden Press.

7. Grobler, A.T. (2005). Product development for community-craft projects in Mpumalanga. An unpublished Masters dissertation,University of Pretoria.

8. Hay, D. (2008). The business of craft and crafting the business: Strategies for success in the rural craft sector.

9. Kedit, P. M. (1989). Iban Cultural Heritage: An Overview of Iban Traditional Cultural Values and Social Norms, and Their Implications for Contemporary Sarawak. Sarawak Museum.

10. Khoo, S. H. (2007). Usaha Sarakraf Pavilon dalam Mengkomersilkan Produk Kraftangan Manik Orang Ulu di Kuching, Sarawak. Sarawak: Universiti Malaysia Sarawak. 
11. Nasir, A. H., \& Wan Teh, W. H. (1997). Warisan seni bina Melayu. Penerbit Universiti Kebangsaan Malaysia.

12. Nor Adila Binti Mohammad. (2013). Strategi peningkatan potensi pelancongan warisan budaya yang efektif di kawasan Batang Ai (Doctoral dissertation, Universiti Malaysia Sarawak).

13. Rasid, M., \& Raman, N. (2015). Penyelidikan Peringkat Sarjana: Pendekatan Kualitatif Sebagai Alternatif. Kota Kinabalau: Universiti Malaysia Sabah.

14. Tugang, N. (2011). Tembikar Dalam Budaya Iban di Sarawak. Sarawak. Malaysia: Universiti Malaysia Sarawak.

15. Tugang, N. A. (2011). Ritual Kain Pua Dalam Budaya Iban di Sarawak (Doctoral dissertation, Universiti Malaya). 